\title{
A Quantitative Study of the Bacteria of a Temporary Pond
}

\author{
By M. FELTON, Jun.,* J. J. COONEY AND W. G. MOORE \\ Department of Biological Sciences, Loyola University, \\ New Orleans, Lousiana, U.S.A.
}

(Accepted for publication 1 November 1966)

\begin{abstract}
SUMMARY
To examine the role of bacteria in the life history of a temporary pond, nine physiological groups of bacteria were determined by plate counts and enrichment culture techniques in pond water, in soil from the pond basin, and in soil from the pinewoods area surrounding the basin. Sampling was begun when the pond was dry and continued through the period when it contained water, into the next dry period. Low counts were obtained for sulphur-, ammonia-, and nitrite-oxidizing autotrophs; iron-oxidizing autotrophs were not detected. This indicates that bacteria did not make a major contribution to the ecosystem as primary producers. Soil samples contained millions to hundreds of millions $\left(10^{6-10^{8}}\right)$ of aerobic nitrogen-fixers and millions to tens of millions $\left(10^{6-10^{7}}\right)$ of urea-utilizing organisms per gramme, suggesting that they may be of significance in the nitrogen cycle in the ecosystem. Hundreds of thousands to tens of millions $\left(10^{\left.5-10^{7}\right)}\right.$ of cellulose-decomposers, and tens of millions to hundreds of millions $\left(10^{7}-10^{8}\right)$ of aerobic and of anaerobic heterotrophs were present per gramme in soil samples. The several heterotrophic types were also present in pond water in maximum numbers ranging from tens of thousands per millitre for nitrogen-fixers to millions per millilitre for anaerobic heterotrophs. As the pond dried the numbers of bacteria in its water decreased. These data suggest that bacteria in the pond ecosystem play a role in the nitrogen, carbon and energy cycles as decomposers and transformers, as a source of nutrilites and as members of the food chain.
\end{abstract}

\section{INTRODUCTION}

Temporary ponds are bodies of water which dry at least once a year (Shelford, 1913; Kenk, 1949; Rzoska, 1961). Their characteristic biota has been enumerated (Shelford, 1913; Jewell, 1927; Rzoska, 1961, and others), but we are aware of no studies dealing with the role of bacteria in such bodies of water. We examined the bacterial flora of one such pond from its dry stage through a cycle of filling and drying. The pond studied was chosen in part because some data were available about its biota (Moore, 1959, 1963) and the chemical composition of its water and soil (Margavio, 1964). The pond was notable for its lack of primary producers (Margavio, 1964), and it was therefore of interest to examine the bacterial flora to determine its role in the cycling of potential food materials.

The pond is located near Florenville, St Tammany Parish, R 14 East, T 7 South, section 19 (Slidell quadrangle), Louisiana, U.S.A. It was designated Station No. 12 by Margavio (1964). When flooded, the pond covers an area of $7350 \mathrm{~m}^{2}$. Its average depth is $75 \mathrm{~cm}$. with a maximum depth of $100 \mathrm{~cm}$. at the centre. The basin contains

* Present address: Department of Biology, Southern University, New Orleans, Louisiana, U.S.A. 
water oak, sweet gum and black gum. Cattle and hogs which roam the area contribute nitrogen from their excreta, and interrupt succession of the basin to dry land by their wallowing. Leaf litter also contributes organic matter to the basin area.

\section{METHODS}

Sampling. Samples were taken over the period from 8 November 1964 to 8 June 1965. The pond's fill history during this period is shown in Fig. 1. Water was first noted in the basin on 27 November 1964; the pond contained water until late April 1965. The first samples were taken when the pond had been dry for 2 weeks. Additional samples were taken when the pond was drying and the last samples were taken when the pond had been dry for 6 weeks.

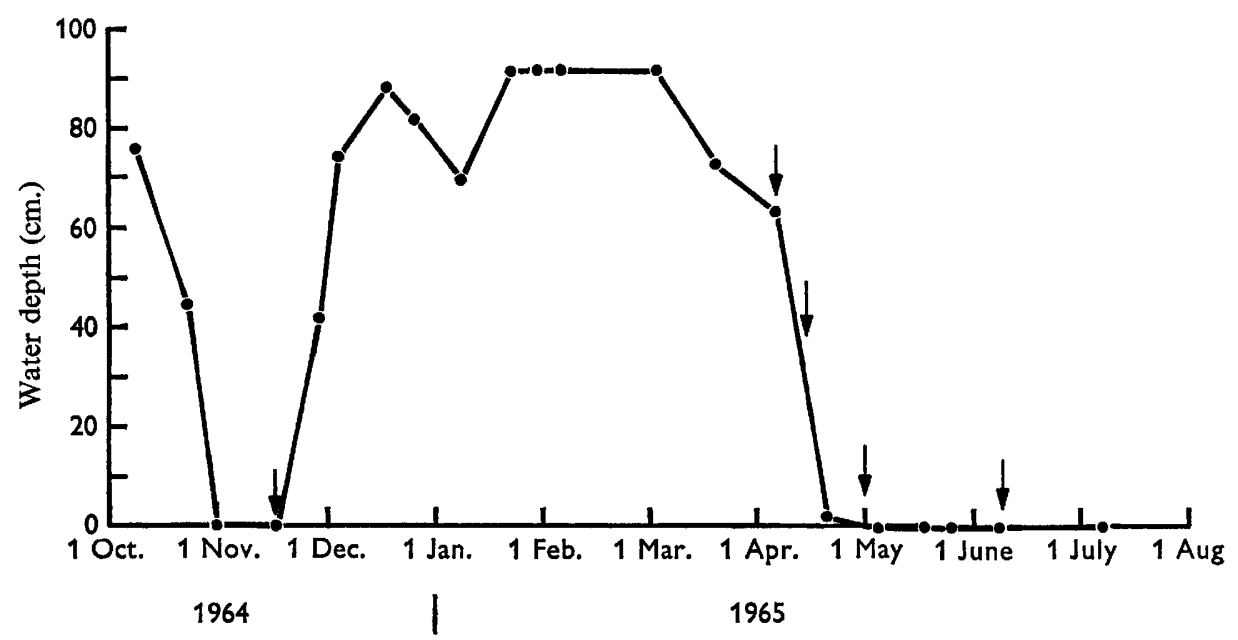

Fig. 1. Fill history of Station No. 12 from October, 1964 to August, 1965. Arrows indicate sampling dates.

Soil samples were taken from pinewood soil in the immediate vicinity of the basin and from the basin proper after the water had receded. An area of forest was cleared of litter and a trenching tool was used to remove a soil sample approximately 3 in. in depth. The sample was placed in a sterile polyethylene bag and the bag was sealed. When the pond contained water, samples were obtained from the approximate centre by submerging a closed sterile polyethylene bag just beneath the surface. The bag was opened, allowed to fill and it was then sealed. Samples were brought to the laboratory and plating was begun immediately.

Microbiological. One-gramme samples of soil were suspended in $99.0 \mathrm{ml}$. sterile distilled water and homogenized in a Waring blendor. Serial tenfold dilutions were prepared from this suspension with $0.85 \% \mathrm{NaCl}$ as diluent. When enumerating autotrophs, $1.0 \mathrm{~g}$. soil was suspended in water and centrifuged at $1200 \mathrm{~g}$ for $30 \mathrm{~min}$. at $20^{\circ}$. The sediment, containing autotrophs (Mayeaux, 1961), was suspended in $99.0 \mathrm{ml}$. water, homogenized and diluted in saline. Water samples were diluted directly in sterile saline. At least three plates were prepared for each dilution plated. The time between sampling and completion of plating was about $3 \cdot 5 \mathrm{hr}$.

Soil extract. Soil extract was prepared by suspending $500 \mathrm{~g}$. soil from the basin in 
$1000 \mathrm{ml}$. distilled water. The suspension was autoclaved and the supernatant fluid passed through a Millipore filter. The liquid portion was used as a medium component $(10 \%, v / v)$ for heterotrophs, nitrogen fixers and urea decomposers. The $\mathrm{pH}$ value of soil extract ranged from $\mathrm{pH} 4 \cdot 4$ to $5 \cdot 6$.

Media. Thornton's (1922) medium was used for aerobic heterotrophs. Anaerobes were plated on Difco nutrient agar. Tubes of agar were held in boiling water for $5 \mathrm{~min}$. before plating to remove dissolved oxygen. Nitrogen fixers were cultivated on Burk's nitrogen-free medium (Wilson \& Knight, 1952).

For cellulose decomposers the basal salts agar of Waksman \& Carey (1926) was used as a base layer in plates. Acid-hydrolyzed cellulose agar (Sarkaris \& Fazal-Ud-Din, 1933) was added as a second layer. Urea soil extract agar (Allen, 1959) was used for urea-utilizing organisms.

The basal salts medium of Stephenson (1949), as modified by Mayeaux (1961), was used to cultivate ammonia oxidizers; the medium contained (g./l. distilled water): $\mathrm{K}_{2} \mathrm{HPO}_{4}, 0.75 ; \mathrm{KH}_{2} \mathrm{PO}_{4}, 0.25 ; \mathrm{FeSO}_{4} .7 \mathrm{H}_{2} \mathrm{O}, 0.01 ; \mathrm{MgSO}_{4} .7 \mathrm{H}_{2} \mathrm{O}, 0.03 ; \mathrm{MnSO}_{4} . \mathrm{H}_{2} \mathrm{O}$, $0.01 ;\left(\mathrm{NH}_{4}\right)_{2} \mathrm{SO}_{4}, 1 \cdot 0$; saturated phenol red solution, $0.20 \mathrm{ml}$. The medium was prepared at double strength and diluted with an equal volume of solidifying agent when preparing plates. Preliminary experiments showed that higher counts were obtained when Ionagar No. 2 was used as solidifying agent than when washed agar or silica gel was used. Ionagar No. 2 (Consolidated Laboratories, Inc., Box 234, Chicago Heights, Illinois, U.S.A.) was prepared according to Bechtle \& Scheer (1958). This medium was also used for nitrite oxidizers, but with $1.0 \mathrm{~g}$. $\mathrm{NaNO}_{2}$ instead of $\left(\mathrm{NH}_{4}\right)_{2} \mathrm{SO}_{4}$.

The mineral base medium of Colmer (1962) and the 9K medium of Silverman \& Lundgren (1959) were both used for autotrophic iron oxidizers; washed agar (Colmer, 1962) or Ionagar No. 2 was used to prepare plates. The medium of Waksman (1922), as modified by Colmer (1962), was used to cultivate autotrophic sulphur oxidizers; washed agar on Ionagar No. 2 was used for plates.

Enrichment cultures. For ammonia oxidizers, $100 \mathrm{ml}$. of a $1 \%$ (w/v) suspension of soil was homogenized in a blendor and transferred to a sterile Erlenmeyer flask. For pond water a $100 \mathrm{ml}$. sample was placed directly in a flask; $10 \mathrm{ml}$. of $10 \%(\mathrm{w} / \mathrm{v})$ filtersterilized $\left(\mathrm{NH}_{4}\right)_{2} \mathrm{SO}_{4}$ were added and the flask incubated on a reciprocal shaker at room temperature $\left(25^{\circ}\right)$. Additional $10 \mathrm{ml}$. portions of $\left(\mathrm{NH}_{4}\right)_{2} \mathrm{SO}_{4}$ solution were added daily for 3 days. After 12 days cultures were removed from the shaker. Cultures prepared from soil samples were centrifuged, the sediment homogenized, diluted and plated to determine whether growth had occurred. Cultures prepared from water samples were diluted directly from enrichment cultures. Enrichment cultures for nitrite oxidizers and iron oxidizers were prepared in the same manner, substituting $10 \%(\mathrm{w} / \mathrm{v})$ solutions of $\mathrm{NaNO}_{2}$ or $10 \% \mathrm{FeSO}_{4} .7 \mathrm{H}_{2} \mathrm{O}$, respectively, for $\left(\mathrm{NH}_{4}\right)_{2} \mathrm{SO}_{4}$.

Spore counts. Soil suspensions were heated at $85^{\circ}$ for $10 \mathrm{~min}$. and appropriate dilutions plated on Thornton's agar.

Incubation. All cultures were incubated at room temperature $\left(25^{\circ}\right)$. Anaerobes were incubated under illuminating (petroleum) gas in a vacuum desiccator. A reduced methylene-blue solution was placed in the desiccator to serve as an indicator of anaerobic conditions (McLung \& Lindberg, 1957).

Colonies were counted after 2-10 days of incubation, depending on the rate of growth of the several types of organisms. 


\section{RESULTS}

The smallest numbers of organisms which could be quantitated accurately from the dilutions plated were $1 \times 10^{5}$ and $1 \times 10^{3}$ for soil and water samples, respectively, although numbers as small as one-tenth of those quantities should have yielded colonies on plates. Numbers of organisms below the sensitivity of the methods used should not play an important role in the life history of the pond.

Table 1. Sample dates, fill history of the pond and numbers of aerobic nitrogen-fixing organisms in soil and water samples

\begin{tabular}{crl}
$\begin{array}{c}\text { Sample } \\
\text { no.* }\end{array}$ & \multicolumn{1}{c}{$\begin{array}{c}\text { Sample } \\
\text { date }\end{array}$} & $\begin{array}{c}\text { Fill history } \\
\text { of pond }\end{array}$ \\
1 & 20 Nov. 1964 & Dry 2 weeks \\
2 & 4 Apr. 1965 & Drying \\
3 & 13 Apr. 1965 & Drying \\
4 & 1 May 1965 & Dry 1 week \\
5 & 8 June 1965 & Dry 6 weeks
\end{tabular}

\begin{tabular}{lll}
\multicolumn{3}{c}{ Colony-forming units from } \\
Pond water & Basin soil & Pinewood soil \\
& $1.8 \times 10^{8} / \mathrm{g}$. & $3.4 \times 10^{8} / \mathrm{g}$. \\
$2.6 \times 10^{4} / \mathrm{ml}$. & $\mathbf{3 . 4 \times 1 0 ^ { 7 } / \mathrm { g } .}$ & $\mathbf{4 . 5} \times 10^{7} / \mathrm{g}$. \\
None & n.d. $\dagger$ & n.d. $\dagger$ \\
: & $3.3 \times 10^{8} / \mathrm{g}$. & $7.9 \times 10^{6} / \mathrm{g}$. \\
& $7.6 \times 10^{7} / \mathrm{g}$. & $7.8 \times 10^{7} / \mathrm{g}$.
\end{tabular}

* In subsequent tables reference to sample data and fill history of the pond will be made by these sample numbers.

$\dagger$ The notation n.d. in this Table and in subsequent Tables indicates that no determination was made.

Table 2. Numbers of aerobic heterotrophs and anaerobic heterotrophs in soil and water samples

\begin{tabular}{|c|c|c|c|c|c|c|}
\hline \multirow[b]{2}{*}{$\begin{array}{c}\text { Sample } \\
\text { no. }\end{array}$} & \multicolumn{3}{|c|}{$\begin{array}{l}\text { Aerobic heterotrophs } \\
\text { colony-forming units from }\end{array}$} & \multicolumn{3}{|c|}{$\begin{array}{l}\text { Anaerobic heterotrophs } \\
\text { colony-forming units from }\end{array}$} \\
\hline & $\begin{array}{l}\text { Pond } \\
\text { water }\end{array}$ & $\begin{array}{c}\text { Basin } \\
\text { soil }\end{array}$ & $\begin{array}{l}\text { Pinewood } \\
\text { soil }\end{array}$ & $\begin{array}{l}\text { Pond } \\
\text { water }\end{array}$ & $\begin{array}{c}\text { Basin } \\
\text { soil }\end{array}$ & $\begin{array}{l}\text { Pinewood } \\
\text { soil }\end{array}$ \\
\hline $\begin{array}{l}1 \\
2 \\
3 \\
4 \\
5\end{array}$ & $\begin{array}{c}1.6 \times 10^{5} / \mathrm{ml} . \\
\text { None } \\
\text {. }\end{array}$ & $\begin{array}{l}5 \cdot 1 \times 10^{8} / \mathrm{g} . \\
4.2 \times 10^{7} / \mathrm{g} \\
\text { n.d. } \\
2.6 \times 10^{7} / \mathrm{g} . \\
7 \cdot 9 \times 10^{8} / \mathrm{g}\end{array}$ & $\begin{array}{l}4.2 \times 10^{7} / \mathrm{g} . \\
2.5 \times 10^{7} / \mathrm{g} . \\
\text { n.d. } \\
1.7 \times 10^{7} / \mathrm{g} . \\
1.5 \times 10^{8} / \mathrm{g} .\end{array}$ & $\begin{array}{c}4.3 \times 10^{6} / \mathrm{ml} \\
2.0 \times 10^{5} / \mathrm{ml} \\
. \\
.\end{array}$ & $\begin{array}{l}5 \cdot 3 \times 10^{8} / \mathrm{g} \\
6 \cdot 9 \times 10^{7} / \mathrm{g} \\
\text { n.d. } \\
2.8 \times 10^{8} / \mathrm{g} \\
6.8 \times 10^{8} / \mathrm{g}\end{array}$ & $\begin{array}{l}2.8 \times 10^{8} / \mathrm{g} \\
2.0 \times 10^{7} / \mathrm{g} . \\
\text { n.d. } \\
2.5 \times 10^{8} / \mathrm{g} \\
9.4 \times 10^{8} / \mathrm{g} .\end{array}$ \\
\hline
\end{tabular}

Basin and pinewood soil yielded $10^{6-10^{8}}$ aerobic nitrogen-fixing organisms/g. soil (Table 1). Pond water contained $2.6 \times 10^{4}$ nitrogen-fixers $/ \mathrm{ml}$. As the pond dried the number in the water decreased below the sensitivity of the method.

Heterotrophs were the largest physiological group isolated from the pond environment. More anaerobes than aerobes were present in pond water, and numbers of both types decreased as the pond dried (Table 2 ). Soil samples contained $10^{7}-10^{8}$ organisms $/ \mathrm{g}$. Each type decreased over the period when the pond was drying and then increased. Anaerobes increased more rapidly than aerobes after the area was dry. Results of heat-shock experiments indicated that approximately $1.5 \%$ of the population of aerobic heterotrophs was composed of heat-resistant (spore) forms.

Bacteria capable of decomposing cellulose were present in pond water and in soil samples (Table 3). Numbers in water decreased as the pond dried. Soil samples taken in the spring yielded fewer cellulose-decomposers than samples taken in the autumn.

Urea-utilizing organisms were present in pond water but decreased below the limits of sensitivity of the method as drying progressed (Table 3). At each sampling interval, 
basin and pinewood soil samples contained approximately the same numbers of urea-using bacteria. Numbers of these organisms in soil samples increased approximately 15 -fold when the pond contained water. A flora of $10^{6-10^{7}} / \mathrm{g}$. soil appeared to be characteristic of soil when the pond was dry.

Sulphur-, ammonia-, or nitrite-oxidizing bacteria were detected in only one group of samples, taken when the area had been dry for 6 weeks (Table 4); nitrite-oxidizing organisms were found only in soil samples from the area outside the pond's perimeter. Enrichment cultures (Table 5) indicated that ammonia-oxidizing organisms were present in all samples, but nitrite-oxidizing organisms were present only in soil samples from outside the area of the basin. Enrichment cultures were not used for sulphuroxidizers. Iron-oxidizing organisms were not detected in any samples by plating or enrichment techniques.

Table 3. Numbers of cellulose-decomposers and urea-utilizing organisms in soil and water samples

Sample
no.
1
2
3
4
5

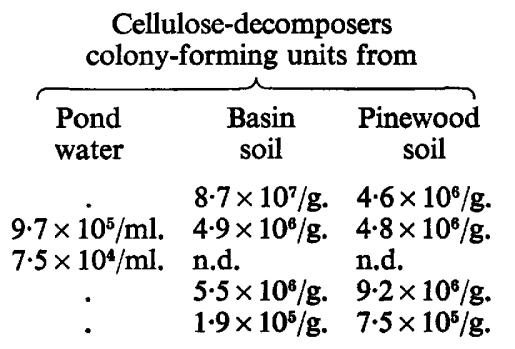

\begin{tabular}{|c|c|c|}
\hline \multicolumn{3}{|c|}{$\begin{array}{l}\text { Urea-utilizing organisms } \\
\text { colony-forming units from }\end{array}$} \\
\hline $\begin{array}{l}\text { Pond } \\
\text { water }\end{array}$ & $\begin{array}{l}\text { Basin } \\
\text { soil }\end{array}$ & $\begin{array}{l}\text { Pinewood } \\
\text { soil }\end{array}$ \\
\hline $10^{5} / \mathrm{ml}$ & $\begin{array}{l}2.0 \times 10^{6} / \mathrm{g} . \\
9 \cdot 3 \times 10^{7} / \mathrm{g} . \\
\text { n.d. } \\
3 \cdot 4 \times 10^{6} / \mathrm{g} . \\
3 \cdot 0 \times 10^{7} / \mathrm{g} .\end{array}$ & $\begin{array}{l}4.6 \times 10^{6} / \mathrm{g} . \\
9.3 \times 10^{7} / \mathrm{g} . \\
\text { n.d. } \\
6.3 \times 10^{6} / \mathrm{g} . \\
1.3 \times 10^{7} / \mathrm{g} .\end{array}$ \\
\hline
\end{tabular}

Table 4. Numbers of sulphur-oxidizing, ammonia-oxidizing and nitrite-oxidizing autotrophs in samples collected 8 June 1965, when the pond had been dry for 6 weeks.

\begin{tabular}{|c|c|c|}
\hline \multirow{2}{*}{$\begin{array}{c}\text { Type of } \\
\text { Type of organism }\end{array}$} & \multicolumn{2}{|c|}{ Colony-forming units from } \\
\hline & Basin soil & Pinewood soil \\
\hline $\begin{array}{l}\text { Sulphur-oxidizing } \\
\text { Ammonia-oxidizing } \\
\text { Nitrite-oxidizing }\end{array}$ & $\begin{array}{l}7 \cdot 0 \times 10^{5} / \mathrm{g} \\
2 \cdot 1 \times 10^{6} / \mathrm{g} \\
\text { None }\end{array}$ & $\begin{array}{l}1.7 \times 10^{5} / \mathrm{g} \\
2.4 \times 10^{6} / \mathrm{g} \\
3.4 \times 10^{4} / \mathrm{g}\end{array}$ \\
\hline
\end{tabular}

Table 5. Results obtained from enrichment cultures.

\begin{tabular}{lccc} 
& \multicolumn{3}{c}{ Growth in cultures prepared in } \\
Type of organism & $\overbrace{\text { Pond water }}$ & Basin soil & Pinewood soil \\
Ammonia-oxidizing & $+*$ & + & + \\
Nitrite-oxidizing & - & - & +
\end{tabular}

* + indicates that growth was observed on plates prepared from enrichment cultures; - indicates that growth was not observed on such plates.

\section{DISCUSSION}

In comparison with other reports (Waksman, 1952), large numbers of nitrogen fixing organisms were detected in this pond ecosystem. Margavio (1964) reported values of $\mathrm{pH} 4 \cdot 9-5 \cdot 5$ for pond water and 4.8-4.9 for soil of Station No. 12. Aerobio 
nitrogen-fixers seldom occur below pH 6.0, although Starkey \& De (1939) reported that Azotobacter indicum grew below pH 6.0 and Ruinen (1956) observed that members of the genus Beijerinckia grew at $\mathrm{pH} 3 \cdot 0$. We did not determine numbers of anaerobic nitrogen-fixers.

In October 1964 hurricane Hilda brought about complete leaf fall. Over the period of this study, estimates of leaf litter ranged from 1186 to $1603 \mathrm{~g} . / \mathrm{m} .{ }^{2}$, and basin and pinewoods soils averaged $32 \%$ and $13.3 \%$ organic matter, respectively. The amount of cellulose and other organic materials undoubtedly contributed to the populations of cellulose-decomposers and other heterotrophs in the pond area. Anaerobic heterotrophs and cellulose decomposers were the only groups present in pond water in sufficient numbers to be quantitated in the latter stages of drying (sample 3, Tables 1-3).

Urea-utilizing organisms were present in significant numbers. Their numbers may have been enhanced by urea from animal sources. These organisms may contribute ammonia to the environment, which may be significant at the level of micro-environment. Margavio (1964) obtained values of 0.65-2.9 p.p.m. for ammonium in pond water from Station No. 12. Ammonia-oxidizing organisms were present in all samples tested (Table 5), but not in significant numbers except for samples taken after the area had been dry for 6 weeks (Table 4). It is therefore difficult to evaluate the role of ammonia-oxidizers in this ecosystem.

Absence of iron-oxidizers was not surprising since soil and water samples contained only 0.48-6.0 p.p.m. of ferrous iron. Except for soil samples taken 8 June 1965, sulphur-oxidizers were evidently present in lower numbers than could be detected by our techniques; this correlates with Margavio's (1964) failure to detect sulphur in the pond environment. The reason for the increase in sulphur-oxidizers after the pond dried is unknown.

As the pond dried the bacterial content of the water decreased. This was probably due to adsorption of bacteria to organic particles which sedimented, and to ingestion of bacteria by organisms higher in the food chain. No other correlation was detected between numbers of bacteria and the stage of the pond's fill history through the single cycle examined.

A complete picture of the role of micro-organisms in the natural history of the pond must await further data, particularly about fungi and protozoa. Additional samples should be taken, particularly during the periods when the pond is filling. However, the numbers of autotrophic organisms indicate that bacteria do not make a significant contribution as primary producers. Aerobic nitrogen-fixers and urea-decomposers may play a significant role in the nitrogen cycle. Together with cellulose-utilizing organisms and other heterotrophs, they may also play a major role in the cycling of carbon and energy in the ecosystem: as decomposers and transformers of organic material, as a source of nutrilites in the pond and in the soil which may be washed into the pond as it fills, and as a primary source of food for protozoa and plankton.

\section{REFERENCES}

Allen, O. N. (1959). Experiments in Soil Bacteriology. Minneapolis, Minn., U.S.A.: Burgess Publ. Co. BeChtLe, R. M. \& ScheER, G. H. (1958). A new agar for in vitro antimicrobial sensitivity testing. Antibiotic \& Chemother. 8, 599.

Colmer, A. R. 1962. Relation of the iron oxidizer, Thiobacillus ferrooxidans to thiosulphate. J. Bact. 83, 761 . 
JEWELL, M. E. (1927). Aquatic biology of the prairie. Ecology 8, 289.

KenK, R. (1949). Animal life of temporary and permanent ponds in southern Michigan. Misc. Publs Mus. Zool. Univ. Mich. no. 71, 66 pp.

MCClunG, L. S. \& LindBerg, R. B. (1957). The study of obligately anaerobic bacteria. In American Society Bacteriologists, Manual of Microbiological Methods, pp. 120-39. New York: McGrawHill Book Co.

MARGAVIo, A. V. (1964). An ecological study of a temporary pond in southeast Lousiana. M.S. Thesis. Loyala Univ., New Orleans, La., U.S.A.

MAYEAUX, J. U. (1961). The effect of some organic herbicides on nitrifying bacteria. M.S. Thesis. Louisiana State Univ., Baton Rouge, La., U.S.A.

MOORE, W. G. (1959). Observations on the fairy shrimp Eubranchipus holmani. Ecology 40, 398.

Moore, W. G. (1963). Some interspecies relationships in Anostraca populations of certain Louisiana ponds. Ecology 44, 131.

RzoskA, J. (1961). Observations on tropical rain in pools and general remarks on temporary waters. Hydrobiologica 17, 265.

RUINEN, J. (1956). Occurrence of Beijerinckia spp. in the phyllosphere. Nature, Lond. 177, 220.

SARKARIS, R. S. \& FAZAL-UD-Din. (1933). A simple method of preparing cellulose (hydrate) for cellulose agar. Indian J. agric. Sci. 3, 365 .

SHElford, V. E. (1913). Animal Communities in Temperate America. Chicago, Illinois, U.S.A.: Univ. Chicago Press.

Silverman, M. P. \& Lundaren, D. G. (1959). Studies on the chemotrophic iron bacterium Ferrobacillus ferrooxidans. J. Bact. 77, 642.

Starkey, R. L. \& De, P. K. (1939). A new species of Azotobacter. Soil Sci. 47, 329.

STEPHENSON, M. (1949). Bacterial Metabolism, 3rd ed. London: Longmans, Green and Co.

Thornton, H. G. (1922). On the development of a standardized agar medium for counting soil bacteria with special regard to the repression of spreading colonies. Ann. appl. Biol. 9, 241.

WAKSMAN, S. A. (1922). Microorganisms concerned in the oxidation of sulphur in the soil. III. Media used for the isolation of sulphur bacteria from the soil. Soil Sci. 13, 329.

Waksman, S. A. (1952). Soil Microbiology. New York, N.Y., U.S.A.: Wiley and Sons.

Waksman, S. A. \& CAREY, C. (1926). The use of the silica gel plate for demonstrating the occurrence and abundance of cellulose-decomposing bacteria. J. Bact. 12, 87.

Wilson, P. W. \& Knight, S. C. (1952). Experiments in Bacterial Physiology. Minneapolis, Minn., U.S.A.: Burgess Publ. Co. 